\title{
Publisher Correction: Migration alters oscillatory dynamics and promotes survival in connected bacterial populations
}

\author{
Shreyas Gokhale (1) ${ }^{1}$, Arolyn Conwill (1) ${ }^{1}$, Tanvi Ranjan (1) ${ }^{2}$ \& Jeff Gore (i) ${ }^{1}$
}

Correction to: Nature Communications; https://doi.org/10.1038/s41467-018-07703-y Published online 10 Dec 2018.

In the original version of this Article, an additional double-headed arrow was inadvertently included within Fig. 3e. This error has been corrected in both the PDF and HTML versions of the Article.

Published online: 12 February 2019

\begin{abstract}
(c) (i) Open Access This article is licensed under a Creative Commons Attribution 4.0 International License, which permits use, sharing, adaptation, distribution and reproduction in any medium or format, as long as you give appropriate credit to the original author(s) and the source, provide a link to the Creative Commons license, and indicate if changes were made. The images or other third party material in this article are included in the article's Creative Commons license, unless indicated otherwise in a credit line to the material. If material is not included in the article's Creative Commons license and your intended use is not permitted by statutory regulation or exceeds the permitted use, you will need to obtain permission directly from the copyright holder. To view a copy of this license, visit http://creativecommons.org/licenses/by/4.0/.
\end{abstract}

(c) The Author(s) 2019

\footnotetext{
${ }^{1}$ Physics of Living Systems, Department of Physics, Massachusetts Institute of Technology, Cambridge, MA 02139, USA. ${ }^{2}$ John A. Paulson School of Engineering and Applied Sciences, Harvard University, Cambridge, MA 02138, USA. Correspondence and requests for materials should be addressed to J.G. (email: gore@mit.edu)
} 